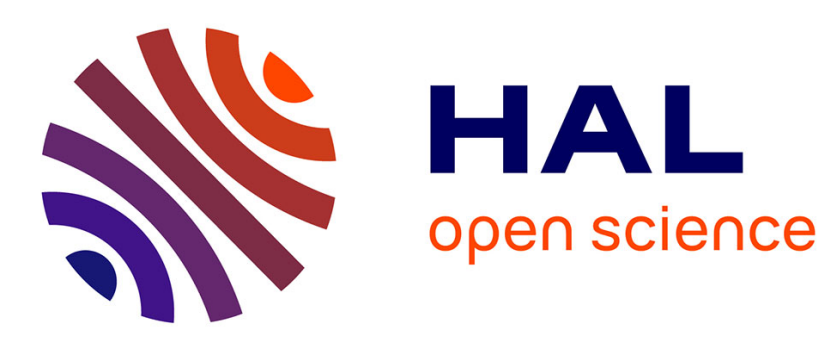

\title{
Effect of weld travel speed on solidification cracking behavior. Part 2: testing conditions and metrics
}

\author{
N. Coniglio, C. E. Cross
}

\section{To cite this version:}

N. Coniglio, C. E. Cross. Effect of weld travel speed on solidification cracking behavior. Part 2: testing conditions and metrics. Int. J. Adv. Manuf. Technol., 2020, 107, pp.5025-5038. 10.1007/s00170-02005232-x . hal-02796820

\section{HAL Id: hal-02796820 \\ https://hal.science/hal-02796820}

Submitted on 5 Jun 2020

HAL is a multi-disciplinary open access archive for the deposit and dissemination of scientific research documents, whether they are published or not. The documents may come from teaching and research institutions in France or abroad, or from public or private research centers.
L'archive ouverte pluridisciplinaire HAL, est destinée au dépôt et à la diffusion de documents scientifiques de niveau recherche, publiés ou non, émanant des établissements d'enseignement et de recherche français ou étrangers, des laboratoires publics ou privés. 


\section{Effect of Weld Travel Speed on Solidification Cracking Behavior. Part 2: testing conditions and metrics}

N. Coniglio ${ }^{a}$ and C.E. Cross ${ }^{b}$

a Laboratory of Mechanics, Surface and Materials Processing (MSMP-EA7350), 2 cours des Arts et Métiers, 13617 Aix-en-Provence - France. Email : nicolas.coniglio@ensam.eu. Phone : 00334 42938183.

${ }^{b}$ Los Alamos National Laboratory (LANL), Los Alamos, NM (United States)

\section{A. ABSTRACT}

Solidification cracking is a weld defect common to certain susceptible alloys rendering many of them unweldable. It forms and grows continuously behind a moving weld pool within the twophase mushy zone and involves a complex interaction between thermal, metallurgical and mechanical factors. Research has demonstrated the ability to minimize solidification cracking occurrence by using appropriate welding parameters. Despite decade's long efforts to investigate weld solidification cracking, there remains a lack of understanding regarding the particular effect of travel speed. While the use of the fastest welding speed is usually recommended, this rule has not always been confirmed on site. Varying welding speed has many consequences both on stress cells surrounding the weld pool, grain structure, and mushy zone extent. Experimental data and models are compiled to highlight the importance of welding speed on solidification cracking. This review is partitioned into three parts: Part I focuses on the effects of welding speed on weld metal characteristics, Part II reviews the data of the literature to discuss the importance of selecting properly the metrics, and Part III details the different methods to model the effect of welding speed on solidification cracking occurrence.

Keywords: solidification cracking; welding; welding speed; crack initiation; crack growth.

\section{B. NOMENCLATURE}

\begin{tabular}{|l|l|}
\hline$h$ & Plate thickness \\
\hline$s$ & Travel speed \\
\hline$t$ & Time \\
\hline$x$ & Direction of heat source displacement \\
\hline
\end{tabular}




\begin{tabular}{|c|l|}
\hline BTR & Brittle Temperature Range \\
\hline CRW & Controlled Restraint Weldability Test \\
\hline CSA & Cross-Sectional Area \\
\hline CSZ & Crack Susceptible Zone \\
\hline EBW & Electron Beam Welding \\
\hline$G$ & Temperature gradient \\
\hline GTAW & Gas Tungsten Arc Welding \\
\hline$I$ & Welding current \\
\hline LBW & Laser Beam Welding \\
\hline LHC & Linear Heat Content \\
\hline MVT & Modified Varestraint-Transvarestraint Test \\
\hline$P$ & Welding power \\
\hline PVR & Program VerformungRisstest \\
\hline$R$ & Solidification growth rate \\
\hline SCTR & Solidification Cracking Temperature Range \\
\hline$T$ & Temperature \\
\hline TVT & Transvarestraint Test \\
\hline$U$ & Welding voltage \\
\hline$\varepsilon$ & Strain \\
\hline$\dot{\varepsilon}$ & Strain rate \\
\hline$\eta$ & Welding efficiency \\
\hline
\end{tabular}

\section{INTRODUCTION}

Solidification cracking is a commonly encountered defect during welding, especially in highsulfur steels, austenitic steels, and aluminum alloys. Solidification cracks form due to a complex interplay of mechanical, thermal, and metallurgical factors. Their formation is strongly dependent on both material composition and welding parameters. To increase productivity, fabricators aim at reducing manufacturing time by increasing welding speed. This commonly implies using laser and electron-beam welding processes that involve welding speeds $\left(10^{1}-10^{2}\right.$ $\left.\mathrm{mm} \cdot \mathrm{s}^{-1}\right)$ faster than commonly encountered in arc welding processes $\left(10^{0}-10^{1} \mathrm{~mm} \cdot \mathrm{s}^{-1}\right)$. However, while the use of fastest travel speeds in arc welding to avoid solidification cracking has been commonly accepted, it seems not to always apply for the faster speeds encountered during beam welding that can lead to numerous weld bead defects [1,2][3] including solidification cracking itself.

Solidification cracking, described by Campbell as "an uniaxial tensile failure in weak materials" [4], appears at the solidification end inside a mushy zone that is subjected to tensile strains. The microstructure forms in the solidification zone, referred to as the mushy zone, located at the rear of the melting zone and bordered by two isothermal surfaces corresponding to liquidus and solidus temperatures. The semi-solid in the mushy zone has little ductility in the terminal stage of solidification, when the liquid fraction is no longer high enough for grains to move around and 
rearrange in order to accommodate tensile strains. When liquid feeding cannot adequately compensate solidification shrinkage and thermal contraction of the mushy zone, solidification cracking occurs along grain boundaries.

Every step forward in understanding alloy behavior improves the ability to elucidate cracking mechanisms and predict alloy weldability. Metrics used to quantify solidification cracking are numerous and depend on the weldability testing device. Most popular metrics are crack length, solidification range, coherency and rigidity points, strain, strain rate, preload, and grain boundary feeding. Data provided by weldability testing enables the selection of proper welding parameters leading to a reduction of solidification crack formation. While the scientific community agrees on the effect of most welding parameters such as the negative effect of increasing current and applied welding tension [5], the effect of travel speed remains a contentious subject. This may be due in part to the fact that, while current controls mainly the weld cross sectional area, travel speed affects both cross sectional area and weld pool shape.

The welding speed effect on solidification crack formation has been studied [6-10], but contradictory results have been obtained. Some works have observed an improvement in wedability when increasing travel speed because of a large compressive cell forming around the mushy zone for GTA welds at speeds in-between 2 and $13 \mathrm{~mm} \cdot \mathrm{s}^{-1}[7,8]$. However some simulation and experiments have shown an increase in cracking susceptibility with increasing travel speed for faster speeds: in-between 2 and $13 \mathrm{~mm} \cdot \mathrm{s}^{-1}$ for GTA [9] and in-between 50 and $100 \mathrm{~mm} \cdot \mathrm{s}^{-1}$ for laser [10] welds. An issue is that travel speed controls both cross-section and elongation of weld pool (current controls only cross-section). Therefore changing travel speed is experimentally done using two different methods: keeping welding parameters constant (i.e. constant welding power) or increase of current to maintain a constant weld shape. It is noted that harmful effects of welding speed can be countered, in whole or in part, with the selection of a proper filler metal. In fact, selecting the correct filler metal leads to a weld metal composition that is little susceptible to solidification cracking, as proven in aluminum alloys [11-18] and stainless steels [19-23].

Little research work has been reported in the literature on the relationship between travel speed and solidification cracking. Scope exists for dealing with solidification cracking by selecting carefully, among other parameters, travel speed. In general, the use of the highest practical welding speeds would be preferable since it produces the lowest crack susceptibility, even though a peak in cracking may possibly occur at intermediate welding speeds. This is encouraging from an economic point of view. The experimental data that highlight the effect of welding speed on solidification cracking susceptibility are reviewed and the selection of appropriate testing conditions and metrics discussed. 


\section{WELDABILITY DATA FROM LITERATURE}

Experimental data on the effect of travel speed on weldability are generated under unique conditions. It is important to detail the experimental conditions and the metrics used and the associated conclusion on the beneficial or deleterious travel speed effect. The examples provided here are numbered and classified through their welding conditions.

\section{Constant power $\mathbf{Q}$}

Several experiments have been performed by investigating the effect of welding speed at constant welding current and thus constant welding power. The aim is to change the only welding speed parameter on the process control and investigate the consequences.

\section{a. Example 1}

The Modified Varestraint Transvarestraint (MVT) test was used to investigate the solidification crack susceptibility of autogenous, partial-penetration GTA steel welds [24]. The chosen steels were DIN 17100-80-St-60-2 (0.2\%C), DIN 17100-80-St-52-3 (0.2\%C + 1.6\%Mn), DIN 17155-83$17 \mathrm{Mn} 4(0.8 \% \mathrm{C}+0.9 \% \mathrm{Mn})$, railway steel $(0.06 \% \mathrm{C}+4.6 \% \mathrm{Mn})$, and $15 \mathrm{NiCrMo} 106(0.14 \% \mathrm{C}+$ $0.29 \% \mathrm{Mn}+2.48 \% \mathrm{Ni})$. The crack index was the total crack length at $4 \%$ applied strain, the ram speed being fixed but with a value not specified. The cracking susceptibility decreases as welding speed increases for a constant heat $Q$ (Table 1 ).

Table 1 conditions required for weld solidification crack formation measured using the MVT weldability test [24].

\begin{tabular}{|c|c|c|c|c|}
\hline Alloy & $\begin{array}{c}\text { Current } \\
\text { (A) }\end{array}$ & $\begin{array}{c}\text { Travel Speed } \\
\left(\mathbf{m m} \cdot \mathbf{s}^{-1}\right)\end{array}$ & $\begin{array}{c}\text { Weldability } \\
\text { Test }\end{array}$ & $\begin{array}{c}\text { Crack Index } \\
\text { Total crack length (mm) at } \\
\text { 4\% applied strain }\end{array}$ \\
\hline DIN 17100-80-St-60-2 & 200 & 11 & MVT & 19.6 \\
\hline DIN 17100-80-St-60-2 & 190 & 18 & MVT & 15.8 \\
\hline DIN 17100-80-St-52-3 & 206 & 11 & MVT & 12.5 \\
\hline DIN 17100-80-St-52-3 & 200 & 18 & MVT & 6.1 \\
\hline DIN 17155-83-17Mn4 & 210 & 11 & MVT & 5.5 \\
\hline DIN 17155-83-17Mn4 & 200 & 18 & MVT & 21.4 \\
\hline Railway steel & 187 & 11 & MVT & 3.1 \\
\hline Railway steel & 183 & 18 & MVT & 3.2 \\
\hline 15 NiCrMo 10 6 & 185 & 11 & MVT & \\
\hline 15 NiCrMo 10 6 & 183 & 18 & MVT & \\
\hline
\end{tabular}

\section{b. Example 2}

The Transvarestraint test (TVT) was used to investigate solidification cracking susceptibility on SS41 steel, partial-penetration, GTA welds [25]. Using crack length indexes, the maximum crack length did not change with welding speed for a fixed current and voltage (Figure 1). The independence of the Crack Susceptible Zone (CSZ) with welding speed for partial-penetration 
welds is in agreement with theoretical calculations of the CSZ length for partial-penetration welds (see Part I of this review). Subsequently crack length criteria were not capable in excessive applied strain conditions to investigate the effect of welding speed on cracking susceptibility. Care must be taken regarding the solidification cracking susceptibility as strains and strain rates applied in the mushy zone during TVT are far exceeding what is needed to initiate solidification cracking [26].

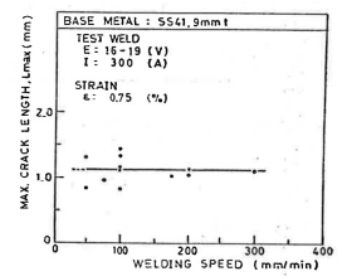

Figure 1 Relationship between maximum crack length and welding speed in Transvarestraint tests for partialpenetration GTA welds of autogenous SS41 steel [25].

\section{c. Example 3}

The solidification cracking susceptibility of autogenous NiCr25FeAlY GTA welds was investigated using the PVR test [27]. The cracking index was the minimum longitudinal tensile speed above which cracking occurs [27]. By maintaining $Q$ constant ( $12 \mathrm{~V}$ and $180 \mathrm{~A}$ ), increasing the welding speed (i.e. smaller $\frac{Q}{S}$ ratio) reduces the cracking susceptibility (Figure 2) [27]. Indeed the critical transverse speed increases from 20.8 to $51.8 \mathrm{~mm} \cdot \mathrm{min}^{-1}$ when increasing travel speed from 1.8 to $3.7 \mathrm{~mm} \cdot \mathrm{s}^{-1}$.
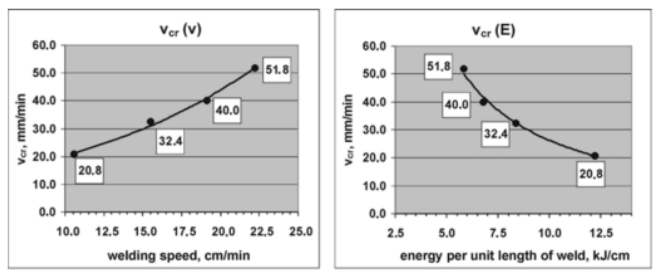

Figure 2 Crack susceptibility of autogeneous NiCr25FeAIY GTA welds measured by PVR testing: (a) welding speed effect and (b) corresponding heat input [27].

\section{d. Example 4}

The Variable Deformation Rate (VDR) cracking test was used to investigate the effect of welding speed on the solidification cracking susceptibility of GTA [28] and MIG aluminum welds [6]. An angular velocity $w_{F}$ is imposed and the minimum deformation rate to stop cracking is measured as the crack susceptibility index. The heat input was constant with a voltage and current of $28 \mathrm{~V}$ and $280 \mathrm{~A}$, respectively. Experimental investigations show that, while increasing welding speed from 6.6 to $13.3 \mathrm{~mm} \cdot \mathrm{s}^{-1}$ at constant power $Q$ (i.e. $\frac{Q}{\mathrm{~s}}$ ratio reduced), the critical deformation rate to maintain crack growth increased from 0.3 to $0.5 \mathrm{~mm} \cdot \mathrm{s}^{-1}$ (Figure 3) [6]. Care must be taken in conclusions as this test investigates the conditions to stop crack growth as the 
other tests investigate conditions to initiate crack growth. Indeed, once the crack forms, all the deformations are occurring in crack opening modifying crack-no crack local conditions. Therefore crack stopping conditions are more severe than crack starting conditions because of strain partitioning specificities across the weld [29].

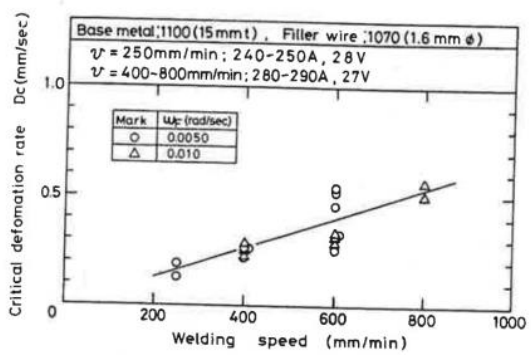

Figure 3 Critical deformation rate measured by VDR testing to maintain crack growth in MIG 1100+1070 aluminum welds [6]

\section{e. Example 5}

Others works have investigated the welding speed effect in laser welding of AA6056 base metal with AA4043 filler [10] and AA6052 base metal with AA4047 filler [30]. Welding parameters were $1.6 \mathrm{~mm}$ thick, butt joint, full penetration, $3 \mathrm{~kW} \mathrm{Nd}$ :YAG. Increasing welding speed $s$ from 50 to $100 \mathrm{~mm} \cdot \mathrm{s}^{-1}$ at constant heat power $Q$ resulted in an increase in solidification cracking susceptibility (Figure 4) [10,30]. This is opposite to previous experimental observations. Nevertheless, these results cannot be used to investigate only the welding speed effect as the filler dilution varied with welding speed. Indeed, maintaining constant wire feeding rate while increasing welding speed leads to smaller filler dilution and higher susceptibility to cracking $[31,32]$ and it has been indeed shown that weld metal silicon content varied for the different welding conditions [30]. Such metallurgy-speed interaction is also true for MIG and MAG welding processes, and therefore care must be taken in generalizing conclusions.

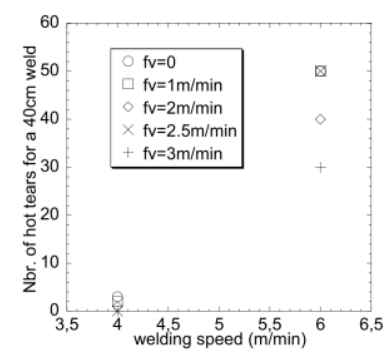

Figure 4 Crack number evolution with welding speed at constant $\mathrm{Q}$ in laser weld of Al 6052 for different amounts of Al 4047 filler metal [30]. $f_{v}$ is filler velocity. 


\section{f. Example 6}

The welding speed effect on solidification cracking was investigated using the free-edge weldability test $[33,34]$. Autogeneous laser welds were performed on TRIP steels using $1100 \mathrm{~W}$ and varying speed from 9 to $12 \mathrm{~mm} \cdot \mathrm{s}^{-1}$ (i.e. $\frac{Q}{s}$ ratio decreased when speed increased). Faster welding speed was associated with a decrease in solidification cracking susceptibility (Figure 5) [33]. This drop in cracking has been associated with smaller thermal strains generated during welding at faster travel speeds (Figure 5b) [33].
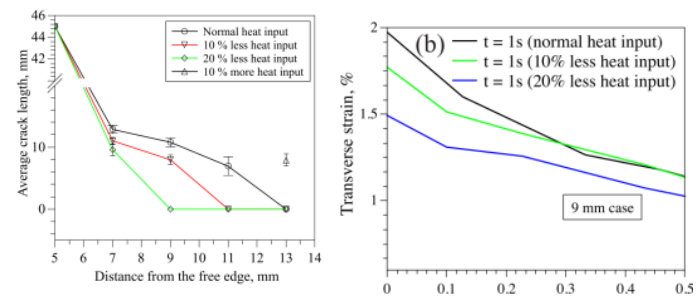

Figure 5 Measurements on autogenous laser beam welds of TRIP steels: (a) crack length as a function of welding speed and restraint conditions (distance from free edge); (b) thermal strain variation with welding speed [33].

\section{g. Example 7}

Solidification cracking susceptibility was investigated in autogenous laser welds of Type 304 stainless steels using the preloading tensile strain (PLTS) cracking test [22]. The base metal was a high-nitrogen stainless steel, nitrogen facilitating austenite formation. Increasing the welding speed from 16 to $50 \mathrm{~mm} \cdot \mathrm{s}^{-1}$ at constant $Q$ increases the solidification cracking susceptibility for both conduction and keyhole mode [22]. This increase has been associated with a change from primary-ferritic to primary-austenitic solidification mode arising from a change in weld metal nitrogen content [22]. Nitrogen was indeed uniformly distributed in a thermal conduction-type weld metal whereas nitrogen content in a keyhole-type weld metal was less at the bead center than on the sides [22].

\section{Constant power-to-speed ratio}

Several experiments have been performed by investigating the effect of welding speed at constant power-to-speed $\frac{Q}{S}$ ratio. The aim is to keep the heat input constant.

\section{a. Example 8}

Weldability of mild steel was investigated for autogenous GTA welds using a test similar to the free-edge test [9]. A crack-no crack index is used. Increasing the welding speed from 8.3 to 12.8 $\mathrm{mm} \cdot \mathrm{s}^{-1}$ increases the solidification cracking tendency. Care must be taken for conclusions as the 
crack forms at the start of the weld (starting on the plate edge) and follows the torch and its is not clearly stated whether $Q$ remains constant or not.

\section{a. Example 9}

The Sigmajig test [35] was used to investigate the solidification cracking susceptibility of the crack-sensitive 316 stainless steel welded with Gas Tungsten Arc (GTAW), Electron Beam (EBW), and Laser Beam (LBW) welding processes [36]. Faster travel speeds decreased solidification cracking susceptibility (Table 2 and Table 3 ) as plotted for GTA welds in Figure 6 . The effect of travel speed has been related to the smaller size of the molten pool and associated lower plastic strains promoted during cooling [36] in agreement with Chihoski's work [37].

Table 2 Percentage of weld length that cracked in Sigmajig weldability test at 207 MPa preload [36].

\begin{tabular}{|c|c|c|c|}
\hline $\begin{array}{c}\text { Alloy } \\
\text { (Base metal + filler metal) }\end{array}$ & $\begin{array}{c}\text { Current } \\
\text { (A) }\end{array}$ & $\begin{array}{c}\text { Travel Speed } \\
\left(\mathbf{m m} \cdot \mathbf{s}^{-1} \text { ) }\right.\end{array}$ & $\begin{array}{c}\text { Crack Index } \\
\text { \% crack at 207 MPa preload }\end{array}$ \\
\hline Autogeneous 316 SS & 20 & 10.4 & 100 \\
\hline Autogeneous 316 SS & 20 & 20.7 & 0 \\
\hline Autogeneous 316 SS & 12 & 8.9 & 0 \\
\hline Autogeneous 316 SS & 28 & 20.7 & 100 \\
\hline
\end{tabular}

Table 3 Minimum preload required for weld solidification crack formation in Sigmajig weldability test [36].

\begin{tabular}{|c|c|c|c|c|}
\hline $\begin{array}{c}\text { Alloy } \\
\text { (Base metal + filler metal) }\end{array}$ & Process & Parameters & $\begin{array}{c}\text { Travel Speed } \\
\left(\mathbf{m m} \cdot \mathbf{s}^{-1}\right)\end{array}$ & $\begin{array}{c}\text { Crack Index } \\
\text { Minimum preload stress for } \\
\text { cracking (MPa) }\end{array}$ \\
\hline Autogeneous 316 SS & GTAW & $28 \mathrm{~A}$ & 20.7 & 48 \\
\hline Autogeneous 316 SS & GTAW & $20 \mathrm{~A}$ & 14.8 & 124 \\
\hline Autogeneous 316 SS & GTAW & $16 \mathrm{~A}$ & 14.8 & 214 \\
\hline Autogeneous 316 SS & GTAW & $20 \mathrm{~A}$ & 20.7 & 214 \\
\hline Autogeneous 316 SS & GTAW & $12 \mathrm{~A}$ & 8.9 & 396 \\
\hline Autogeneous 316 SS & EBW & $1.0 \mathrm{~mA}$ & 14.8 & 379 \\
\hline Autogeneous 316 SS & EBW & $1.5 \mathrm{~mA}$ & 29.6 & 345 \\
\hline Autogeneous 316 SS & EBW & $2.0 \mathrm{~mA}$ & 44.5 & 448 \\
\hline Autogeneous 316 SS & LBW & $107 \mathrm{~W}$ & 14.8 & 414 \\
\hline Autogeneous 316 SS & LBW & $274 \mathrm{~W}$ & 22.2 & 379 \\
\hline Autogeneous 316 SS & LBW & $314 \mathrm{~W}$ & 29.6 & \\
\hline
\end{tabular}

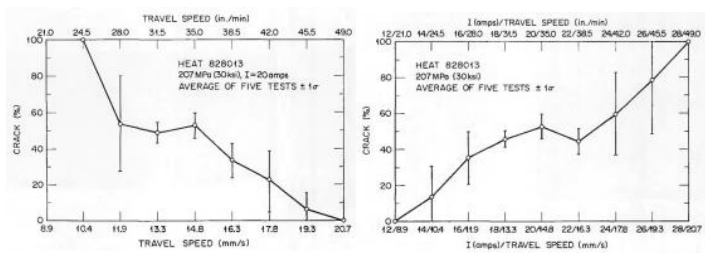


Figure 6 crack susceptibility of 316 SS GTA welds measured using Sigmajig test - Effect of (a) travel speed and (b) $Q / \mathrm{s}$ ratio [36].

\section{b. Example 10}

The circular patch test was used to investigate the solidification cracking susceptibility of Incoloy A-286 autogeneous GTA welds [5]. The patch test is a popular test as marked effects on cracking susceptibility are produced by changing, among others, current (250 to $350 \mathrm{~A}$ ) and welding speed (5 to $10 \mathrm{~mm} \cdot \mathrm{s}^{-1}$ ) [5]. Increasing the welding speed s at constant heat $\mathrm{Q}$ (i.e. $\frac{Q}{\mathrm{~s}}$ ratio decreased) decreases the cracking susceptibility (horizontal displacement towards the left in Figure 7) possibly due to the associated smaller cross-sectional area [5]. Now, considering the simultaneous increase of $Q$ and $s$ while maintaining an overall $\frac{Q}{s}$ ratio constant, increasing $s$ increases solidification crack susceptibility. This work highlighted a correlation between increased cross-sectional area (CSA) and higher solidification cracking susceptibility. A threshold CSA of $18.5 \mathrm{~mm}^{2}$ has been found as a maximum not to exceed to avoid solidification cracking (Table 4) [5].

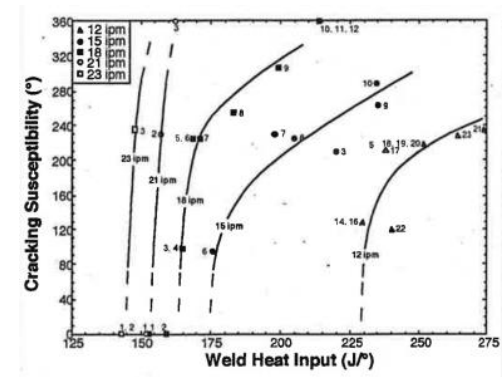

Figure 7 Crack-no crack boundary conditions for A-286 autogeneous GTA welds performed in patch tests [5].

Table 4 conditions required for weld solidification crack formation of Autogeneous A-286 GTA welds measured by the Patch weldability test. Voltage was constant at $10.5 \mathrm{~V}$ [5].

\begin{tabular}{|c|c|c|c|}
\hline $\begin{array}{c}\text { Current } \\
(\mathbf{A})\end{array}$ & $\begin{array}{c}\text { Travel Speed } \\
\left(\mathbf{m m} \cdot \mathbf{s}^{-\mathbf{1}} \mathbf{)}\right.\end{array}$ & $\begin{array}{c}\text { Crack Index } \\
\text { Degree for crack initiation }\end{array}$ & $\begin{array}{c}\text { Cross-sectional } \\
\text { area }\left(\mathbf{m m}^{\mathbf{2}} \mathbf{)}\right.\end{array}$ \\
\hline 250 & 5.1 & 218 to 245 & 14.8 to 15.8 \\
\hline 260 & 5.1 & 149 & 14.5 \\
\hline 275 & 5.1 & 113 to 162 & 16.4 to 17.9 \\
\hline 300 & 5.1 & 125 & 19.5 \\
\hline 240 & 6.4 & 265 & 13.7 \\
\hline 270 & 6.4 & 130 & 16.3 \\
\hline 280 & 6.4 & 135 & 16.5 \\
\hline 300 & 6.4 & 150 & 17.9 \\
\hline 320 & 6.4 & 75 to 119 & 18.3 to 20.2 \\
\hline 250 & 7.6 & 360 & 13.9 \\
\hline 260 & 7.6 & 360 & 13.3 \\
\hline 270 & 7.6 & 250 to 305 & 13.6 to 14.2 \\
\hline 275 & 7.6 & 219 to 231 & 13.9 to 15.1 \\
\hline 280 & 7.6 & 138 & 15.0 \\
\hline
\end{tabular}




\begin{tabular}{|c|c|c|c|}
\hline 300 & 7.6 & 105 & 16.0 \\
\hline 325 & 7.6 & 54 & 18.4 \\
\hline 350 & 7.6 & 0 & 17.6 to 22.5 \\
\hline 290 & 8.9 & 360 & 13.4 \\
\hline 300 & 8.9 & 130 & 14.2 \\
\hline 310 & 8.9 & 33 & 14.7 \\
\hline 300 & 9.7 & 360 & 12.7 to 13.7 \\
\hline 310 & 9.7 & 124 & 14.3 \\
\hline
\end{tabular}

\section{Constant weld size}

Several experiments have been performed by investigating the effect of welding speed at constant weld size that is adjusting current to maintain either a weld penetration or a weld width.

\section{a. Example 11}

Butt welds were performed by Shielded Metal Arc (SMAW) and Gas Metal Arc (GMAW) welding on API-5L-X60 and X70 grades of line-pipes [38]. Current and travel speed varied over a wide range of values. A simple crack-no crack index is used. A crack-no crack boundary for welds is defined on a travel speed-carbon content map (Figure 8). All grades and welding configurations show a threshold carbon content. For compositions smaller than the threshold carbon content, an increase in welding speed increases the solidification crack susceptibility of SMA and GTA weld metals. Travel speed variations do not affect solidification cracking susceptibility in weld metals containing high carbon contents.

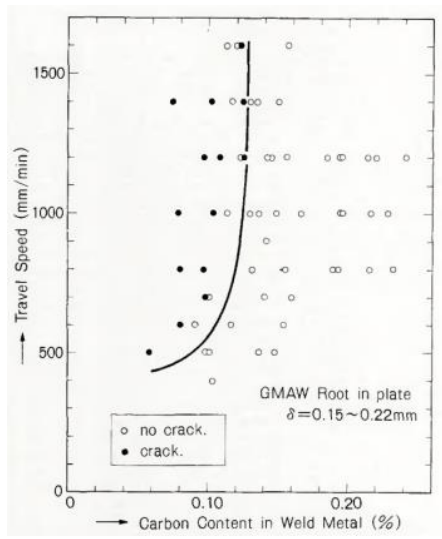

Figure $\mathbf{8}$ Critical conditions for solidification cracking in GMA welds of line-pipe steels for the root pass deposited in U-grooves [38].

\section{b. Example 12}

The Sigmajig weldability test was applied to investigate the effect of welding speed on fullpenetration, autogenous GTA welds of a nickel-based superalloy similar in composition to IN-738 [39]. Welding speed varied from 4.2 to $14.8 \mathrm{~mm} \cdot \mathrm{s}^{-1}$ and current was adjusted from 32 to $75 \mathrm{~A}$ to maintain a constant weld size. Crack index was the percentage of weld metal cracked with a 
transverse preload of $172 \mathrm{MPa}$. The results show that faster welding speeds increase solidification cracking susceptibility (Table 5) [39].

Table 5 Table 2 Percentage of weld length that cracked in Sigmajig weldability test at 172 MPa preload for GTA welds of IN-738 alloy [39].

\begin{tabular}{|c|c|c|c|}
\hline $\begin{array}{c}\text { Voltage } \\
\text { (V) }\end{array}$ & $\begin{array}{c}\text { Current } \\
\text { (A) }\end{array}$ & $\begin{array}{c}\text { Travel Speed } \\
\left(\mathbf{m m} \cdot \mathbf{s}^{-1} \text { ) }\right.\end{array}$ & $\begin{array}{c}\text { Crack Index } \\
\text { \% of crack at 172 MPa preload }\end{array}$ \\
\hline 9 & 32 & 4.2 & 50 \\
\hline 10 & 75 & 14.8 & 100 \\
\hline
\end{tabular}

\section{c. Example 13}

Niel et al. [40] investigated the effect of current and welding speed on weldability of autogenous AA6061 GTA welds. The weldability test consists in applying a longitudinal tensile stress on the bead-on-plate weld during welding. Current and speed were adjusted to maintain full-penetration. A constant longitudinal preload of $200 \mathrm{MPa}$ is applied prior to welding and a crack-no crack boundary is determined in a current-speed map (Figure 9). At constant heat $Q$, increasing the welding speed $s$ reduces crack susceptibility.

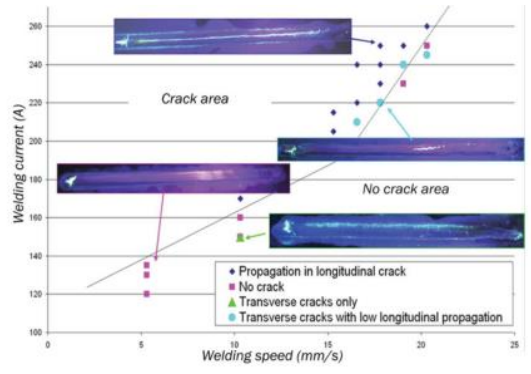

Figure 9 crack-no crack boundary condition in a current-speed map for autogenous AA6061 GTA welds [40].

\section{d. Example 14}

Welding speed effect on weldability was investigated for laminated AA6061-T6 plates welded in full-penetration, keyhole mode, using a Yb-YAG laser in continuous wave mode [41]. Welding speed varied from 25 to $83 \mathrm{~mm} \cdot \mathrm{s}^{-1}$ and power was adjusted from 4 to $8 \mathrm{~kW}$, respectively, to maintain full-penetration and similar cross section [41]. Using the Controlled Restraint Weldability (CRW) test showed that increasing welding speed and simultaneously laser power reduces the solidification cracking susceptibility [41]. This is in agreement with arc weldability data [7,32] but in opposition with some laser weldability data [10,30]. This disagreement may possibly arise from the methodology as other works maintain constant laser power while varying welding speeds. 


\section{e. Example 15}

Welding speed effect was investigated in overlap, full-penetration laser welds of autogenous AIMgSi alloys [42]. Solidification cracking susceptibility was quantified by measuring with DIC the minimum local strain rate for cracking. Weldability of these alloys was improved at high silicon and high titanium contents, associated with easy liquid feeding and refined grain structure, respectively. Weldability was nevertheless also affected by the welding parameters. Welding speed varied from 50 to $150 \mathrm{~mm} \cdot \mathrm{s}^{-1}$ and laser power was adjusted from 3 to $6 \mathrm{~kW}$ to maintain full-penetration welds. Smaller welding speeds enlarge the top width of weld pool because of high thermal losses transverse to the welding direction and therefore accompanied with larger grain structures due to smaller cooling rates. Nevertheless the width of the centerline equiaxed zone was larger at slow welding speeds (Figure 10a). This combination of more equiaxed grain boundaries leads to a better weldability at slow welding speed despite the fact that the welds were wider and microstructure coarser. Increasing $s$ and $Q$ simultaneously increased the cracking susceptibility (Figure 10b).

(a)

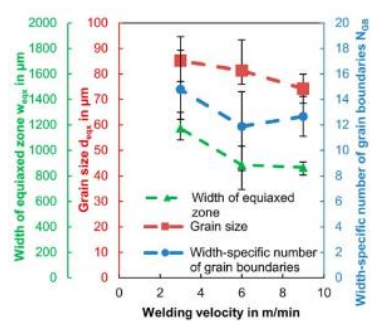

(b)

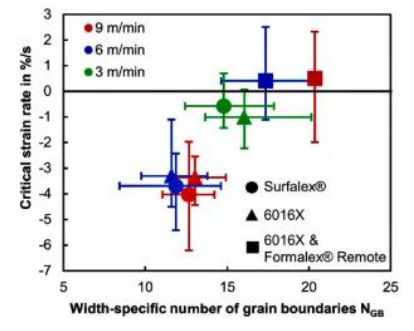

Figure 10 overlap, autogenous laser welds of AIMgSi Alloys. Relationship between welding speed with (a) grain size and (b) critical strain rate for cracking [42].

\section{f. Example 16}

Solidification cracking susceptibility of GTA low-alloy steel welds was investigated using the Varestraint and Huxley weldability tests [43]. Current was adjusted to maintain a constant weld width (corresponding approximately to $\frac{Q^{3 / 2}}{s}$ or $I=38+25 s$ [43]). There exists at faster speeds a competition between trailing edge elongation (i.e. hindering of liquid feeding and thus greater cracking susceptibility) and smaller tensile stresses surrounding the mushy zone (i.e. smaller susceptibility to cracking) [43]. This has led to the finding of a welding speed that corresponds to the peak of cracking. Interestingly and in a controversial manner, there existed a welding speed of $5.1 \mathrm{~mm} \cdot \mathrm{s}^{-1}$ where shrinkage on welding is minimum and thus should be a sign of minimum tensile stress [7].

\section{g. Example 17}

Different levels of known harmful (e.g. C, S, P) and beneficial (e.g. O) impurities in regards to solidification cracking were tested by using the Huxley test on low alloy steels [43][44]. Indeed, segregates of low melting temperatures may persist as grain-boundary films well below the 
effective alloy solidus [45-47]. This was confirmed by post-mortem analysis that revealed enrichment in impurities at solidification crack surfaces [48]. Low levels of impurities limit the CSZ length [49] so that fast welding speeds are needed to extend the CSZ enough to get lack of liquid feeding and thus cracking [43]: if $\frac{Q}{S}$ decreases then cracking susceptibility increases (Figure 11a). In opposite, high level of impurities leads to extensive CSZ (difficult liquid feeding and thus easy cracking) and therefore the dominant effect is the shift of compressive cells to CSZ [43]: if $\frac{Q}{S}$ decreases then cracking susceptibility decreases (Figure 11b). It must be noted that, even though C, S, P impurities deteriorate cracking resistance, eliminating all impurities such as sulfur leads to outward Marangoni flows and thus impede the weld penetration. Changes in interfacial tension driven fluid flow affect the liquid feeding ability and can subsequently influence the solidification cracking susceptibility of a microstructure [50].

(a)

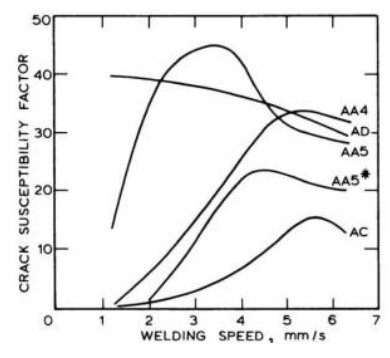

(b)

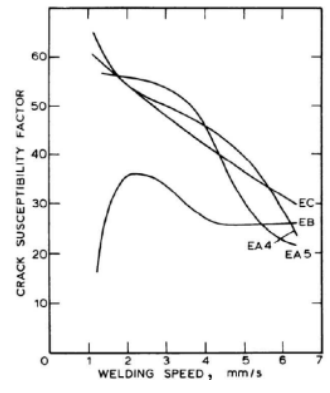

Figure 11 Huxley test results on GTA low alloy steel welds with C, S, and P impurities at (a) low and (b) high amounts [43].

\section{E. PRACTICAL IMPLICATIONS}

The experimental data reviewed in this paper show that the conclusions of the harmful or beneficial effect of increasing travel speeds depend on the weld metal chemistry, the welding conditions (i.e. the choice of maintaining constant either $Q, \frac{Q}{s}$, or weld size), the welding process, and the parametrics. These ambiguous conclusions are summarized in Table 6 . While the consequences in maintaining either $Q$ or $\frac{Q}{s}$ constant have been discussed in Part I, the importance of the metrics is clearly highlighted from the experimental data. Indeed, quantitative assessment of cracking susceptibility is a debated subject and subsequently numerous metrics are proposed to quantify a susceptibility to cracking.

Table 6 Summary of experimentally-measured travel speed effect on weld solidification cracking formation. 


\begin{tabular}{|c|c|c|c|c|c|c|c|c|}
\hline $\begin{array}{l}\text { Base metal alloy } \\
\text { (+ filler metal) }\end{array}$ & Process & $\underset{\text { constant }}{\frac{Q}{S}}$ & $\underset{\text { constant }}{\mathbf{Q}}$ & $\begin{array}{l}\text { Cross sectional } \\
\text { area constant }\end{array}$ & $\begin{array}{l}\text { Weldability } \\
\text { Test }\end{array}$ & $\begin{array}{l}\text { Crack susceptibility changes } \\
\text { when increasing travel speed }\end{array}$ & Metrics & Ref. \\
\hline $\begin{array}{c}\text { DIN } 17100-80-S t-60-2 \\
\text { DIN } 17100-80-S t-52-3 \\
\text { DIN } 17155-83-17 M n 4 \\
\text { railway steel } \\
15 \text { NiCrMo } 106\end{array}$ & GTA & No & Yes & No & MVT & Susceptibility reduced & Crack length & {$[24]$} \\
\hline SS41 & GTA & No & Yes & No & TVT & Susceptibility unchanged & Crack length & [25] \\
\hline 316 SS & GTA & No & Yes & No & $\begin{array}{l}\text { Sigmajig } \\
\text { Test }\end{array}$ & Susceptibility reduced & Crack length & {$[36]$} \\
\hline $\begin{array}{c}\text { Autogeneous } \\
\text { NiCr25FeAlY }\end{array}$ & GTA & No & Yes & No & PVR Test & Susceptibility reduced & $\begin{array}{l}\text { longitudinal } \\
\text { tensile speed }\end{array}$ & [27] \\
\hline $\begin{array}{c}\text { Autogeneous } \\
\text { A-286 }\end{array}$ & GTA & No & Yes & No & Patch Test & Susceptibility reduced & Crack length & {$[5]$} \\
\hline AA6061 & GTA & No & Yes & No & $\begin{array}{l}\text { Longitudina } \\
\text { I Preload }\end{array}$ & Susceptibility reduced & Crack length & {$[40]$} \\
\hline AA1100 (+ AA1070) & MIG & No & Yes & No & VDR test & Susceptibility reduced & $\begin{array}{c}\text { minimum } \\
\text { deformation rate }\end{array}$ & {$[6]$} \\
\hline AA1100 & GTA & No & Yes & No & VDR test & Susceptibility reduced & $\begin{array}{c}\text { minimum } \\
\text { deformation rate }\end{array}$ & {$[6]$} \\
\hline AA6056(+AA4043) & LBW & No & Yes & No & Butt welds & Susceptibility increased & Crack length & {$[10]$} \\
\hline AA6052 (+AA4047) & LBW & No & Yes & No & Butt welds & Susceptibility increased & Crack length & {$[30]$} \\
\hline $\begin{array}{l}\text { Autogeneous } \\
\text { TRIP steel }\end{array}$ & LBW & No & Yes & No & $\begin{array}{c}\text { Free-edge } \\
\text { Test }\end{array}$ & Susceptibility reduced & local strain rate & {$[33,34]$} \\
\hline AA2024 & EBW & No & Yes & No & - & Susceptibility reduced & Crack length & [51] \\
\hline 304 SS & LBW & No & Yes & No & PLTS & Susceptibility reduced & Crack length & {$[22]$} \\
\hline 316 SS & GTA & Yes & No & No & $\begin{array}{l}\text { Sigmajig } \\
\text { Test }\end{array}$ & Susceptibility increased & Preload & [36] \\
\hline $\begin{array}{c}\text { Autogeneous } \\
\text { A-286 }\end{array}$ & GTA & Yes & No & No & Patch Test & Susceptibility increased & Crack length & {$[5]$} \\
\hline $\begin{array}{l}\text { Low alloy steel with } \\
\text { high impurity levels }\end{array}$ & GTA & Yes & No & No & Huxley Test & Susceptibility reduced & Crack length & {$[43]$} \\
\hline $\begin{array}{l}\text { Low alloy steel with } \\
\text { small impurity levels }\end{array}$ & GTA & Yes & No & No & $\begin{array}{l}\text { Varestraint } \\
\text { test }\end{array}$ & Susceptibility increased & Crack length & {$[43]$} \\
\hline $\begin{array}{l}\text { API-5L-X60 } \\
\text { API-5L-X70 }\end{array}$ & $\begin{array}{l}\text { SMA and } \\
\text { GTA }\end{array}$ & No & No & Yes & Root weld & Susceptibility increased & Crack length & [38] \\
\hline Ni-based superalloy & GTA & No & No & Yes & $\begin{array}{l}\text { Sigmajig } \\
\text { Test }\end{array}$ & Susceptibility increased & Crack length & [39] \\
\hline AA6061 & GTA & No & No & Yes & $\begin{array}{l}\text { Longitudina } \\
\text { I Preload }\end{array}$ & Susceptibility increased & Crack length & {$[40]$} \\
\hline AA6061-T6 & LBW & No & No & Yes & CRW & Susceptibility reduced & Crack length & {$[41]$} \\
\hline $\mathrm{Ti}+\mathrm{Nb}$ containing steel & GTA & No & No & Yes & MVT & Susceptibility reduced & Crack length & {$[52]$} \\
\hline AlMgSi alloys & LBW & No & No & Yes & $\begin{array}{l}\text { Overlap } \\
\text { weld }\end{array}$ & Susceptibility increased & local strain rate & {$[42]$} \\
\hline
\end{tabular}

\section{Local metrics}

Some metrics are local and characterize the solidification cracking susceptibility inherent to the mushy zone. These metrics include solidification range and local strain. They enable a quantification of the grain boundary feeding ability as this is one condition for solidification crack formation. Indeed, a solidification crack forms for a lack in grain boundary liquid feeding which is related to long grain boundary channels (i.e. large solidification ranges) and inability to sustain large openings (i.e. small critical strain and strain rate). 
The critical solidification range has been quantified in terms of BTR and SCTR indexes (Figure 12). These indexes are theoretically bound by the coherency and rigidity temperatures and not the solidus and liquidus temperatures. This criterion is not always an accurate predictor, but the SCTR index has proven a useful representation of weldability. The CSZ length, measured using the Varestraint test, increased with increasing travel speed, which is in agreement with the extended trailing edge at fast welding speeds [43]. Nevertheless, the Huxley cracking susceptibility and the CSZ measurement with Varestraint did not always correlate (Figure 11) [43], questioning the use of the CSZ value as a unique and representative index for cracking susceptibility. The critical solidification range is therefore not a characteristic of the alloy alone.

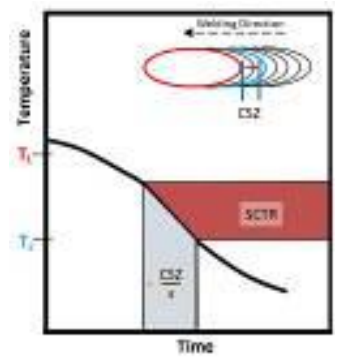

Figure 12 Two standpoints for relationship between BTR (equals to the ratio CSZ/s with $s$ the welding speed) and SCTR cracking indexes highlighting the effect of welding speed [26].

Critical strains and strain rates are interesting measurements as some models suggest them to be the driving force of solidification crack formation for a given microstructure and solidification conditions [29,53]. These measurements are difficult to perform because they must be performed in-situ and near to the mushy zone. This is important as the strains in the mushy zone can exceed, by several orders of magnitude, the overall applied strain [26]. Of particular interest are the digital image correlation (DIC) methods that enable the contactless measurements of strain fields behind the weld pool [54]. These measurements quantify the position of crack tip and the strain conditions to form a crack moreover to the thermal stress fields surrounding the weldment and their evolution with welding parameters $[42,55,56]$. These measurements are useful experimental data to implement both inherent condition for cracking and thermo-field change with welding speed into 3D Multiphysics modeling [57].

\section{Global metrics}

Global metrics measure the macroscopic conditions to induce solidification cracking. As local metrics must be used to understand the microscopic mechanics, global metrics are necessary to understand the coupling between metallurgical modifications and thermal strain field involvement. Moreover to the popular crack length indexes, preloading force [58] and restraint intensity [59] have been successful. Crack length indexes have been nonetheless most popular. 
Crack lengths are the most popular metrics and are useful for comparisons and rankings [60] but do not provide a fundamental characteristic of an alloy. Moreover, which cracks are to be included in this metric is a debatable subject as intermittent cracks may not be considered [5] even though it has been demonstrated that an intermittent crack represents a condition for initiation, but not for propagation at a particular welding speed [29]. Because cracking depends on weldment geometry, the crack length metrics may be more comparable if using the ratio of crack lengths on cross-sectional areas [61]. Issues remain in comparing different alloys at the same heat input and manufacturing a testing device that leads to high repeatability of crack length indexes [26].

It is interesting to note that all these criteria characterize the susceptibility of a microstructure to form solidification cracking. When considering the overall effect of travel speed on solidification cracking, none of these local criteria considers the change of thermal strain cells surrounding the mushy zone. Only macroscopic criteria (restraint conditions and even the most popular "go versus no-go" indexes) are capable of quantifying the overall effect of travel speed. Many other metrics exist but their harmonization to enable their direct comparison and even lead to one single criterion is a contentious subject [62].

\section{Measuring cracking susceptibility}

Measuring crack length metrics or crack-no crack macro-conditions [15,43,59,62,63] will provide an overall point of view of the interaction between microstructure and process-induced thermo-mechanical fields. However, if local measurements are applied [31,55,56,64], then thermal-induced strains are not accounted for and only the inherent susceptibility of a microstructure to cracking are evaluated. Therefore, increasing welding speed may lead to a more susceptible microstructure (e.g. from local strain measurements) but simultaneously improve weldability because of a compressive stress field forming around the mushy zone. Therefore, local strain rate measurements such as MISO $[56,65,66]$, extensometer $[31,67]$, and DIC [55] estimate the only susceptibility change due to alloy differences.

Measurements that uniquely define weldability are still debated and must be associated to standardized weldability testing procedures [68]. The CSZ measurement is particularly well suited to fast-applied stresses, such as the Varestraint and Transvarestraint tests. Preloaded tests, such as the Sigmajig, Houldcroft, and CRW tests, measure conditions to arrest crack growth during welding. Finally, tests varying conditions during welding until a solidification crack forms, such as the CTW test, estimate conditions to initiate solidification cracking. Therefore, different tests measure different aspects of the solidification cracking phenomenon. Which aspect is most important for welding speed study is a contentious subject. 


\section{F. CONCLUSIONS}

Several issues have been pointed out when investigating the effect of welding speed. The first issue is the experimental welding conditions: should we maintain $\mathrm{Q}$ constant, $\mathrm{Q} / \mathrm{s}$ constant, or the weld width constant? The second issue is dependence of the harmful-versus-beneficial response with the selected metrics.

When considering crack length, it is usually a macroscopic stage of observations. This means that the effect of travel speed is an overview of both microstructural and thermo-mechanical changes; especially it includes the variation in tensile and compressive cells (magnitude and position) along the trailing edge of the weld pool. However, when considering local conditions for cracking (such as local strain and strain rate), then only the microstructural component is tested and thus an inherent property of the cracking susceptibility of the weld mushy zone is provided.

\section{G. REFERENCES}

[1] T.C. Nguyen, D.C. Weckman, D.A. Johnson, H.W. Kerr, High speed fusion weld bead defects, Sci. Technol. Weld. Join. 11 (2006) 618-633. https://doi.org/10.1179/174329306X128464.

[2] T.C. Nguyen, D.C. Weckman, D.A. Johnson, H.W. Kerr, The humping phenomenon during high speed gas metal arc welding, Sci. Technol. Weld. Join. 10 (2005) 447-459. https://doi.org/10.1179/174329305X44134.

[3] J.R. Pickens, The weldability of lithium-containing aluminium alloys, J. Mater. Sci. 20 (1985) 4247-4258. https://doi.org/10.1049/ep.1966.0223.

[4] J. Campbell, Castings, Elsiever, 2003.

[5] T.W. Nelson, J.C. Lippold, W. Lin, W.A. Baeslack III, Evaluation of the Circular Patch Test for Assessing Weld Solidification Cracking, Part I Development of a Test Method, Weld. J. (1997) 110-119.

[6] A. Matsuda, H. Nakagawa, K. Nakata, H. Okada, The VDR cracking test for solidification crack susceptibility on weld metals and its application to aluminum alloys, Trans. JWRI. 8 (1979) 85-95.

[7] R.A. Chihoski, The Character of Stress Fields Around a Weld Arc Moving on Aluminum Sheet, Weld. J. 168 (1972) 9s-18s.

[8] O. Hunziker, D. Dye, S.M. Roberts, R.C. Reed, A coupled approach for the prediciton of solidification cracking during the welding of superalloys, in: Hot Crack. Phenom. Welds, 
Springer, 2005: pp. 299-319.

[9] M. Shibahara, H. Serizawa, H. Murakawa, Finite element method for hot cracking analysis using temperature dependent interface element, in: Hot Crack. Phenom. Welds, Springer, 2005: pp. 253-257.

[10] E. Cicală, G. Duffet, H. Andrzejewski, D. Grevey, S. Ignat, Hot cracking in Al-Mg-Si alloy laser welding - Operating parameters and their effects, Mater. Sci. Eng. A. 395 (2005) 1-9. https://doi.org/10.1016/j.msea.2004.11.026.

[11] J.H. Dudas, F.R. Collins, Preventing Weld Cracks in High-Strength Aluminum Alloys, Weld. J. 45 (1966) 241s-249s.

[12] J.D. Dowd, weld cracking of aluminum alloys, Weld. J. 31 (1952) 448s-456s.

[13] P.H. Jennings, W.T. Pumphrey, A.T.I.E. Soltðus, A consideration of the constitution of aluminium-iron-silicon alloys and its relation to cracking above the solidus, JIM. 44 (1948) 249-258.

[14] P.H. Jennings, A.R.E. Singer, W.T. Pumphrey, Hot shortness of some high-purity alloys in the systems aluminium-copper-silicon and aluminium-magnesium-silicon, JIM. 74 (1948) 227-248.

[15] M.M. Mossman, J.C. Lippold, Weldability Testing of Dissimilar Combinations of 5000- and 6000-Series Aluminum Alloys, Weld. J. (2002) 188-194.

[16] M.G. Mousavi, C.E. Cross, O. Grong, The effect of high-temperature eutectic-forming impurities on aluminum 7108 weldability, Weld. J. 88 (2009) 104-110. http://0.0.2.53.

[17] M.G. Mousavi, C.E. Cross, $\varnothing$. Grong, M. Hval, Controlling weld metal dilution for optimised weld performance in aluminium, Sci. Technol. Weld. Join. 2 (1997) 275-278. https://doi.org/10.1179/stw.1997.2.6.275.

[18] N. Coniglio, C.E. Cross, T. Michael, M. Lammers, Defining a critical weld dilution to avoid solidification cracking in aluminum, Weld. J. 87 (2008) 237s-247s.

[19] C.E. Cross, N. Coniglio, E.M. Westin, A. Gumenyuk, Laser weldability of stainless steel, in: Hot Crack. Phenom. Welds III, Springer, 2011: pp. 131-144. https://doi.org/10.1007/9783-642-16864-2-8.

[20] D.E. Nelson, W.A. Baeslack-III, J.C. Lippold, An Investigation of Weld Hot Cracking in Duplex Stainless Steels, Weld. J. 66 (1987) 241s-250s.

[21] M.J. Cieslak, A.M. Ritter, W.F. Savage, Solidification cracking and analytical electron microscope of austenite stainless steel weld metals, Weld. J. 61 (1982) 1s-8s.

[22] K. Nishimoto, H. Mori, Hot cracking susceptibility in laser weld metal of high nitrogen stainless steels, Sci. Technol. Adv. Mater. 5 (2004) 231-240. 
https://doi.org/10.1016/j.stam.2003.10.006.

[23] C.D. Lundin, C.P.D. Chou, Hot Cracking Susceptibility of Austenitic Stainless Steel Weld Metals, Weld. $\quad$ Res. $\quad$ Counc. $289 \quad$ (1983) 1-79. http://www.aws.org/wj/supplement/WJ_1982_03_s82.pdf.

[24] A. Ankara, H.B. Ari, Determination of hot crack susceptibility in various kinds of steels, Mater. Des. 17 (1996) 261-265. https://doi.org/10.1038/447149a.

[25] T. Senda, T., Matsuda, F., Takano, G., Watanabe, K., Kobayashi, T., Matsuzaka, Fundamental investigations on solidification crack susceptibility for weld metals with trans-varestraint test, Trans. JWS. 2 (1971) 1-22. https://doi.org/10.2207/qjjws1943.41.709.

[26] D. Statharas, H. Atkinson, R.O.B. Thornton, Getting the Strain Under Control: TransVarestraint Tests for Hot Cracking Susceptibility, Metall. Mater. Trans. A. 50 (2019) 17481762. https://doi.org/10.1007/s11661-019-05140-0.

[27] A. Slyvinsky, H. Herold, M. Streitenberger, Influence of Welding Speed on the Hot Cracking Resistance of the Nickel-Base Alloy NiCr25FeAlY During TIG-Welding, in: Crack. Phenom. Mech., 2003: pp. 42-58.

[28] Y. Arata, F. Matsuda, K. Nakata, K. Shinozaki, Solidification crack susceptibility of aluminum alloy weld metals (Report III), Trans. JWRI. 6 (1977) 47-52.

[29] N. Coniglio, C.E. Cross, Mechanisms for solidification crack initiation and growth in aluminum welding, Metall. Mater. Trans. A. 40 (2009) 2718-2728. https://doi.org/10.1007/s11661-009-9964-4.

[30] D. Fabrègue, A. Deschamps, M. Suéry, H. Proudhon, Hot Tearing During Laser Butt Welding of 6xxx Aluminium Alloys : Process Optimisation and 2D / 3D Characterisation of Hot Tears, in: Hot Crack. Phenom. Welds II, 2007: pp. 241-253.

[31] N. Coniglio, C.E. Cross, T. Michael, M. Lammers, Defining a critical weld dilution to avoid solidification cracking in aluminum, Weld. J. (Miami, Fla). 87 (2008).

[32] N. Coniglio, C.E. Cross, Weld parameter and minor element effects on solidification crack initiation in aluminium, in: Hot Crack. Phenom. Welds II, Springer, 2008: pp. 277-310.

[33] G. Argawa, H. Gao, M. Armithalingam, M. Hermans, Study of Solidification Cracking Susceptibility during Laser Welding in an Advanced High Strength Automotive Steel, Metals (Basel). 8 (2018) 1-15. https://doi.org/10.3390/met8090673.

[34] V. Ploshikhin, A. Prikhodovsky, M. Makfiurin, A. liin, Integrated mechanical-metallurgical approach to modeling of solidification cracking in welds, in: Hot Crack. Phenom. Welds, Springer, Berlin, Heidelberg, 2005: pp. 223-244.

[35] G.M. Goodwin, Development of a New Hot-Cracking Test - The Sigmajig, Weld J (Miami Fla). (1987) 33s-38s. 
[36] G.M. Goodwin, The Effects of Heat Input and Weld Process on Hot Cracking in Stainless Steel, Weld. J. (1988) 88s-94s.

[37] B.Y.L. Johnson, Formation of Plastic Strains During Welding of Aluminum Alloys, Weld. J. 52 (1973) 298s-305s.

[38] S. Ohshita, N. Yurioka, N. Mori, T. Kimura, Prevention of Solidification Cracking in Very Low Carbon Steel Welds, Weld. J. 283 (1983) 129s-136s.

[39] Z. Feng, T. Zacharia, S. David, On the thermomechanical conditions for weld metal solidification cracking, in: Math. Model. Weld Phenom. 3, The Institute of Materials, 1996: pp. 114-148.

[40] A. Niel, F. Deschaux-beaume, C. Bordreuil, G. Fras, J.-M. Drezet, Hot tearing test for TIG welding of aluminum alloys: application of a stress parallel to the fusion zone, in: Hot Crack. Phenom. Welds III, 2011: pp. 43-58. https://doi.org/10.1007/b139103.

[41] N. Coniglio, M. Patry, Measuring laser weldability of aluminium alloys using controlled restraint weldability test, Sci. Technol. Weld. Join. 18 (2013) 573-580. https://doi.org/10.1179/1362171813Y.0000000137.

[42] C. Hagenlocher, D. Weller, R. Weber, T. Graf, Reduction of the hot cracking susceptibility of laser beam welds in AIMgSi alloys by increasing the number of grain boundaries, Sci. Technol. Weld. Join. (2018) 1-7. https://doi.org/10.1080/13621718.2018.1534775.

[43] E.J. Morgan-Warren, M.F. Jordan, Effect of travel speed on solidification cracking in autogenous tungsten inert gas arc welding of low- alloy steel sheet, Met. Technol. (1976) 29-40. https://doi.org/10.1179/030716976803391421.

[44] Y. Arata, F. Matsuda, K. Nakata, S. Katayama, Solidification Crack Susceptibility in Weld Metals of Fully Austenitic Steels (Report II) - Effect of Ferrite, P, S, C, Si, and Mn on Ductility Properties of Solidification Brittleness, Trans. JWRI. 6 (1977) 105-117.

[45] G.J. Davies, J.G. Garland, Solidification Structures and Properties of Fusion Welds, Int. Metall. Rev. 20 (1975) 83-108.

[46] J.C. Borland, Suggested explanation of hot cracking in mild and low alloy steel welds, Br. Weld. J. (1961) 526-540.

[47] J.C. Borland, Generalized theory of supersolidus cracking in welds (and castings), Br. Weld. J. (1960) 508-512.

[48] S.A. David, C.L. White, Formation of Hot Cracks in Austenitic Stainless Steel Welds Solidification Cracking, Weld. Res. Suppl. 209-s (1986) 203-212.

[49] Z. Sterjovski, C. Bayley, J. Donato, N. Lane, D. Lang, Weld-End Solidification Cracking in Pulsed-Tandem Gas Metal Arc Welding of Naval Steels, Weld. J. 93 (2014) 145s-152s. 
[50] M. Holt, D.L. Olson, C.E. Cross, Interfacial tension driven fluid flow model for hot cracking, Scr. Metall. Mater. 26 (1992) 1119-1124.

[51] S.A. Hosseini, A. Abdollah-zadeh, H. Naffakh-Moosavy, A. Mehri, Elimination of hot cracking in the electron beam welding of AA2024-T351 by controlling the welding speed and heat input, J. Manuf. Process. $46 \quad$ (2019) 147-158. https://doi.org/10.1016/j.jmapro.2019.09.003.

[52] D.S. Konadu, P.G.H. Pistorius, M. Du Toit, A. Griesche, Solidification cracking susceptibility of ferritic stainless steels using Modified Varestraint Transvarestraint (MVT) method, Sadhana - Acad. Proc. Eng. Sci. 44 (2019) 13-15. https://doi.org/10.1007/s12046-019$1175-0$.

[53] M. Rappaz, J. Drezet, M. Gremaud, A New Hot-Tearing Criterion, 30 (1999) 449-455.

[54] N. Coniglio, A. Mathieu, O. Aubreton, C. Stolz, Plasma effect on weld pool surface reconstruction by shape-from- polarization analysis, Appl. Phys. Lett. 104 (2014) 131603. https://doi.org/10.1063/1.4870505.

[55] N. Bakir, V. Pavlov, S. Zavjalov, S. Volvenko, A. Gumenyuk, M. Rethmeier, Development of a novel optical measurement technique to investigate the hot cracking susceptibility during laser beam welding, Weld. World. (2018).

[56] F. Matsuda, H. Nakagawa, S. Tomita, Quantitative evaluation of solidification brittleness of weld metal during solidificaiton by in-situ observation and measurement (Report III), Trans. JWRI. (1986) 125-133.

[57] H.R.Z. Rajani, A.B. Phillion, 3D multi-scale multi-physics modelling of hot cracking in welding, Mater. Des. 144 (2018) 45-54. https://doi.org/10.1016/j.matdes.2018.02.007.

[58] T. Zacharia, Dynamic stresses in weld metal hot cracking, Weld. J. (Miami, Fla). (1994) 164172.

[59] C.E. Cross, T. Bollinghaus, The Effect of Restraint on Weld Solidification Cracking in Aluminum, Weld. World. 50 (2006) 51-54.

[60] C. V Robino, M. Reece, G.A. Knorovsky, J.N. DuPont, Z. Feng, Prediction of Maximum Crack Length in Longitudinal Varestraint Testing, ASM Proc. Int. Conf. Trends Weld. Res. (2005) 313-318. papers3://publication/uuid/33CA970E-E705-4ED5-9186-31FE74E62377.

[61] N.L. Richards, R. Nakkalil, M.C. Chaturvedi, The Influence of Electron-Beam Welding Parameters on Heat-Affected-Zone Microfissuring in INCOLOY 903, Met. Mat. Trans. A. 25 (1994) 1733-1745.

[62] R. Sandstrom, harmonisation of weldability data for aluminum alloys, in: 5th Ina. Conf. Alum. Weldments, Munich, 1992: pp. 5.3.1-5.3.14.

[63] T. Soysal, S. Kou, A simple test for assessing solidification cracking susceptibility and 
checking validity of susceptibility prediction, Acta Mater. 143 (2018) 181-197. https://doi.org/10.1016/j.actamat.2017.09.065.

[64] N. Coniglio, C.E. Cross, Weld parameter and minor element effects on solidification crack initiation in aluminium, in: Hot Crack. Phenom. Welds II, 2008.

[65] F. Matsuda, K. Nakata, S. Harada, Moving characteristics of weld edges during solidification in relation to solidification cracking in GTA weld of aluminum alloy thin sheet, Trans. JWRI. 9 (1980) 83-93.

[66] F. Matsuda, H. Nakagawa, H. Kohmoto, Y. Honda, Y. Matsubara, Quantitative Evaluation of Solidification Brittleness of Weld Metal during Solidification by In-situ Observation and Measurement (Report II), Trans. JWRI. (1983) 73-80.

[67] T. Kannengiesser, T. Mclnerney, W. Florian, T. Bollinghaus, C.E. Cross, The influence of local weld deformation on hot cracking susceptibility, in: Proc. 6th Int. Semin. Numer. Anal. Weldability, Graz, Austria, 2001: pp. 1-19.

[68] N. Coniglio, C.E. Cross, Towards Establishment of Weldability Testing Standards for Solidification Cracking, in: Hot Crack. Phenom. Welds IV, 2016: pp. 37-66. 